\title{
Thermal imaging to phenotype traditional maize landraces for drought tolerance
}

\author{
Ivan Francisco Garcia Tejero', Joaquim Miguel Costa', Roberta Samara Nunes da Lima', \\ Victor Hugo Duran Zuazo', Maria Manuela Chaves², Maria Carlota Vaz Patto²
}

'Instituto de Investigación y Formación Agrária y Pesquera, Centro "Las Torres-Tomejil", Sevilla, España Instituto de Tecnología Química e Biológica António Xavier, Universidade NOVA de Lisboa, Oeiras, Portugal Corresponding author, e-mail: victorh.duran@juntadeandalucia.es

\begin{abstract}
Searching and identification of new crops or varieties with higher adaptation or resistance to water stress is one of the strategies to make agriculture profitable and more sustainable. Especially en arid and semi areas with limiting water resources. This study establishes a practical, fast and replicable protocol to select maize genotypes for its capability to respond to water stress. Eight Portuguese maize landraces (LD), traditionally grown in areas with different altitude and subjected to potentially different degrees of water stress (low altitude = potentially lower stress; high altitude = potentially higher stress) was used. Seedlings were subjected to continuous watering (FI) or forced to water withholding (non-irrigated) for a period of 7-8 days followed by re-watering (NI). Leaf temperature was determined every $48 \mathrm{~h}$ by thermal imaging and the temperature difference between $\mathrm{NI}$ and Fl plants $\left(\Delta T_{N-F)}\right)$ was calculated. We found that those genotypes that traditionally had been grown at higher altitudes kept more stable leaf temperature values under dry or wet conditions (small $\Delta \mathrm{T}_{\mathrm{N} \text { - }}$ F) even under severe water stress. These results will help to optimize a screening protocol for maize seedlings and select novel genotypes or LDs better adapted to water stress, especially in regions where irrigation water is scarce.
\end{abstract}

Keywords: maize, genotypes, water stress, leaf temperature, fast plant screening

\section{Uso da termografia para fenotipagem da tolerância à seca de populações tradicionais de milho}

\section{Resumo}

A pesquisa e a identificação de novas espécies cultivadas ou de variedades melhor adaptadas ou mais resistentes a condições de seca é uma forma de tornar a agricultura não só mais rentável mas também mais sustentável. Isto é especialmente importante para regiões de clima árido ou semi-árido e com recursos hídricos escassos. O estudo aqui apresentado estabelece um protocolo prático, rápido e replicável para selecionar genótipos de milho em termos da sua capacidade de resposta à seca. Foram testadas oito populações de milho tradicional português (LD), cultivadas a diferentes altitudes e potencialmente expostos a diferentes graus de secura (baixa altitude = potencialmente menor exposição; alta altitude = potencialmente maior exposição ao stress hídrico). As plântulas foram submetidas a rega contínua (FI) ou a condições de seca durante 7-8 dias seguidas de re-hidratação(NI). A temperatura da folha foi determinada cada $48 \mathrm{~h}$ por termografia. Foi calculada a diferença de temperatura entre plantas NI e FI ( $\Delta \mathrm{T} \mathrm{NI}-\mathrm{FI})$. Verificamos que as linhas tradicionais cultivadas a maior altitude mantiveram valores mais estáveis da temperatura na folha em condições de rega ou de seca severa (valor pequeno do $\Delta \mathrm{TNI}-\mathrm{Fl}$ ). Este estudo contribuirá para optimizar um protocolo de seleção de plântulas de milho e de linhagens melhor adaptadas á seca, o que é especialmente relevante para a agricultura em regiões áridas, com recursos hídricos escassos e sem posssibilidade de rega.

Palavras-chave: estresse hídrico, genótipos, milho, screen rápido de plantas. temperatura foliar 


\section{Introduction}

Water is the most limiting natural resource in agriculture, mainly in arid and semiarid Mediterranean areas of southern Europe. Since adoption of the European Water Framework Directive to the latest proposals of the Common Agriculture Policy "Horizon 2020", the EU Council has defined several strategic lines to establish a balance between agriculture and environmental conservation. These strategies have been oriented to optimize the use of natural resources, to guarantee food supply, food quality and diversity of products in sustainable context. Therefore, a more efficient and rational use of the existing biodiversity and a faster and more robust selection of plants/genotypes more resistant to drought is envisaged (García-Tejero et al., 2013).

Maize (Zea mays L.) is a highly relevant crop worldwide, with an annual production of $853 \times 10^{6}+$ year $^{-1}$ (Vasconcellos e Souza, 2012). This crop is also a major water consumer in irrigated areas of the Mediterranean region, where grain yields can reach $10-12$ t ha $^{-1}$ under irrigated and proper fertilization conditions (Hoeft et al., 2000; Farré \& Faci, 2006). On the other hand, low input farming systems in dry areas are threatened by increasing unfavorable climate conditions (more severe drought, extreme temperatures) events which do limit yield and put in risk the profits of small farmers (García-Tejero et al., 201 lb).

Portugal has more than 137,000 ha of agricultural land devoted to maize, corresponding to the $40 \%$ of total surface to cereals crops, and an annual production close to 700,000 † (Vasconcellos \& Souza, 2012). Numerous and highly diverse landraces (LDs) have been developed in Portugal in the last five centuries of cultivation. Many of these LDs are still cultivated nowadays because they are well adapted to specific regional growing conditions and to small farmers needs (Vaz Patto et al., 2009). These landraces are open pollinated varieties (OPVs), and contrary to hybrids, they do not require controlled pollination for seed production and pollination occurs via wind pollination. These LDs represent important sources of interesting genes and/or gene combinations not yet available for maize breeding.

The traditional Portuguese LDs demonstrate quality over yield (Vaz Patto et al., 2007). In fact, they are still cultivated not because of their high yields, but rather because of their higher yield stability. This has been accomplished by successive generations of natural and deliberate selection of favorable alleles for resistance to biotic and abiotic stresses, with maintenance of high genetic diversity (Vaz Patto et al., 2004) to increase adaptability to a large variety of edapho/climatic conditions, such as drought (Pêgo \& Antunes, 1997).

Some traditional maize cultivars, have been grown for long time by farmers at different altitudes and have been subjected to natural stressfully conditions, and naturally selected for improved adaptation to drought (Carvalho et al., 2011). To promote on-farmconservation and more efficient use of the maize Portuguese LDs, a participatory plant breeding program has been established in Portugal since the 80's (Pêgo \& Antunes, 1997, Vaz Patto et al., 2013). The program engages local farmers and their maize LDs, safeguarding against an unpredictable future. Farmers are invited to interact with breeders in their own farm and intervene at different stages of the breeding program, such as the generation of diversity, selection and seed multiplication. Consequently, selection criteria must consider farmers objectives, like pest and disease resistance, but also enhanced capacity to survive in highly changeable environments (e.g. more severe drought) typical of low input farming systems. New maize OPV, that better meet farmers' needs (Mendes-Moreira et al., 2008, 2009), and that conserve crop genetic diversity and quality (Vaz Patto et al. 2008, 2009), are being developed within this program. In order to increase efficiency of this or other more conventional maize breeding programs, it is important to develop fast, efficient and low cost selection protocols to support selection criteria, particularly in what concerns traits related to drought tolerance.

Leaf gas exchange measurements offer direct and often robust information on plant physiological condition and genetic variability, namely in terms of plants photosynthetic and transpirational activity under water stress situations (Long \& Bernacchi, 2003). In this line, 
a partial or total stomatal closure promotes a decreasing in leaf transpiration and hence, a direct effect in the evaporative cooling process, resulting in an increment in leaves temperatures (Jones, 1992; Kummerlen et al., 1999; Jones \& Vauhan, 2010). According to this, many authors have reported the possibility of estimating the stomatal conductance on the basis of canopy temperature (Jones, 1999, García-Tejero et al., 2011 a; Costa et al., 2013).

Plant phenotyping for drought tolerance based on leaf gas exchange is complex and time consuming and can show poor repeatability due to the high stomatal sensitivity to small changes in environmental conditions (James \& Siraut, 2012). Thermal imaging emerged as a non-invasive promising technique to monitor remotely and non-destructively crop's water status based on the inverse relation between leaf temperature and transpiration rate (Kummerlen et al., 1999; Jones \& Vauhan, 2010). This technique allows the graphical representation of spatial distribution of plant's surface temperature by sensing the infrared radiation emitted (and reflected) by the crop.

The main objective of this work was to set up and test a fast and replicable protocol to phenotype maize plants at early stages and select superior genotypes/LDs in terms of their resistance to water stress based on thermal imaging measurements. To that extent we carried out a preliminary characterization of eight Portuguese traditional LDs grown and selected under different altitude conditions and subjected to different potential degrees of water stress (low altitude = less stress; high altitude = more stress).

\section{Material and Methods}

Plant material and growth conditions

The study was developed in two different periods, from $26^{\text {th }}$ August (238 day of the year, DOY) to $16^{\text {th }}$ September (259 DOY) (Experiment I), and from $22^{\text {th }}$ September (265 DOY) to $15^{\text {th }}$ October (288 DOY) (Experiment II). Eight local Portuguese maize open pollinated LDs were used. These LDs were selected from a wider collection of Portuguese maize germplasm presently under selection as part of the national participatory maize breeding program (Vaz Patto et al., 2007, 2013). Their selection was based on the different altitude of their traditional cultivating location and potential exposure to dry conditions. Seeds were kindly provided by Pedro Mendes-Moreira (ESAC). Table 1 displays the main characteristics for each maize landrace used for the experiment according to Vaz Patto et al. (2007).

Table 1. General maize (Zea Mays L.) characteristics for the eight Portuguese landraces tested in the present study

\begin{tabular}{|c|c|c|c|}
\hline Landraces & Seed colour & Cultivation altitude (m a.s.I.) & Collecting location (GPS) \\
\hline LD 44 & White & 338 & $40^{\circ} 25^{\prime} 326^{\prime \prime} \mathrm{N} 7^{\circ} 55^{\prime} 323^{\prime \prime} \mathrm{W}$ \\
\hline LD 43 & Yellow & 338 & $40^{\circ} 25^{\prime} 326^{\prime \prime} \mathrm{N} 7^{\circ} 55^{\prime} 323^{\prime \prime} \mathrm{W}$ \\
\hline LD 4 & Yellow & 411 & $40^{\circ} 36^{\prime} 11$ 1'N 7050'50' 'W \\
\hline LD 3 & White & 411 & $40^{\circ} 36^{\prime} 11$ l'N 7050'50' 'W \\
\hline LD 30 & White & 530 & $40^{\circ} 40^{\prime} 295^{\prime \prime} \mathrm{N} 70^{\circ} 0^{\prime} 193^{\prime \prime} \mathrm{W}$ \\
\hline LD 28 & Yellow & 530 & $40^{\circ} 40^{\prime} 295^{\prime \prime} \mathrm{N} 70^{\circ} 50^{\prime} 193^{\prime \prime} \mathrm{W}$ \\
\hline LD 9 & White & 862 & $40^{\circ} 53^{\prime} 765^{\prime \prime} \mathrm{N} 7^{\circ} 42^{\prime} 505^{\prime \prime} \mathrm{W}$ \\
\hline LD 10 & Yellow & 862 & $40^{\circ} 53^{\prime} 765^{\prime \prime} \mathrm{N} 7^{\circ} 42^{\prime} 505^{\prime \prime} \mathrm{W}$ \\
\hline
\end{tabular}

We used 30 seeds per variety in each trial. Seeds were pre-germinated in dark conditions, on a wet filter paper in Petri dishes under controlled environment $\left(27^{\circ} \mathrm{C}\right.$ in darkness during $72 \mathrm{~h}$ (Figure 1a). After this, uniformly germinated seeds were selected and sown in plastic pots $(9 \mathrm{~cm} \times 9 \mathrm{~cm} \times 11 \mathrm{~cm}$ ) filled with a soil mixture (Figure 1b) and placed in greenhouse under semi-controlled conditions, sowing one seed per pot. Once plants had reached the 2-3 leaves stage; eight uniformly developed seedlings were selected. Four of them were subjected to full irrigation conditions (FI), with a soil-water content at field capacity; and the remaining four were subjected to non-irrigation conditions (NI) during a period of 7-8 days, till the soil-water depletion was close to zero (considering this point close to the permanent wilting point), followed by rehydratation. 
Thermal imaging and plant growth measurements

Thermal images were obtained using a ThermaCAM (Flir SC660, Flir Systems Inc., USA, 7-13 $\mu \mathrm{m}, 640 \times 480$ pixels) with an emissivity set at 0.96 . The camera was mounted at a height, at $1.6 \mathrm{~m}$ above the ground and placed at $1.5 \mathrm{~m}$ distance from plants (Figure 1c). One image per treatment and variety was taken, $\mathrm{NI}$ and immediately after Fl. Previously to each measurement cycle, background temperature was determined by measuring the temperature of a crumpled sheet of aluminum foil in a similar position to the leaves of interest with the emissivity set at 1.0 (Jones et al., 2002). Thermal images were taken every $48 \mathrm{~h}$, between 12:00 and 13:00 solar time, being analyzed with the software FLIR QuickReport 1.2 (FLIR Systems, Inc., USA) (Figure 1d), The temperature of 2-3 leaves per plant was measured, using the function area to select each leaf and take the respective average temperature. We have also recorded visible images (RGB) to complement analysis of thermal images.

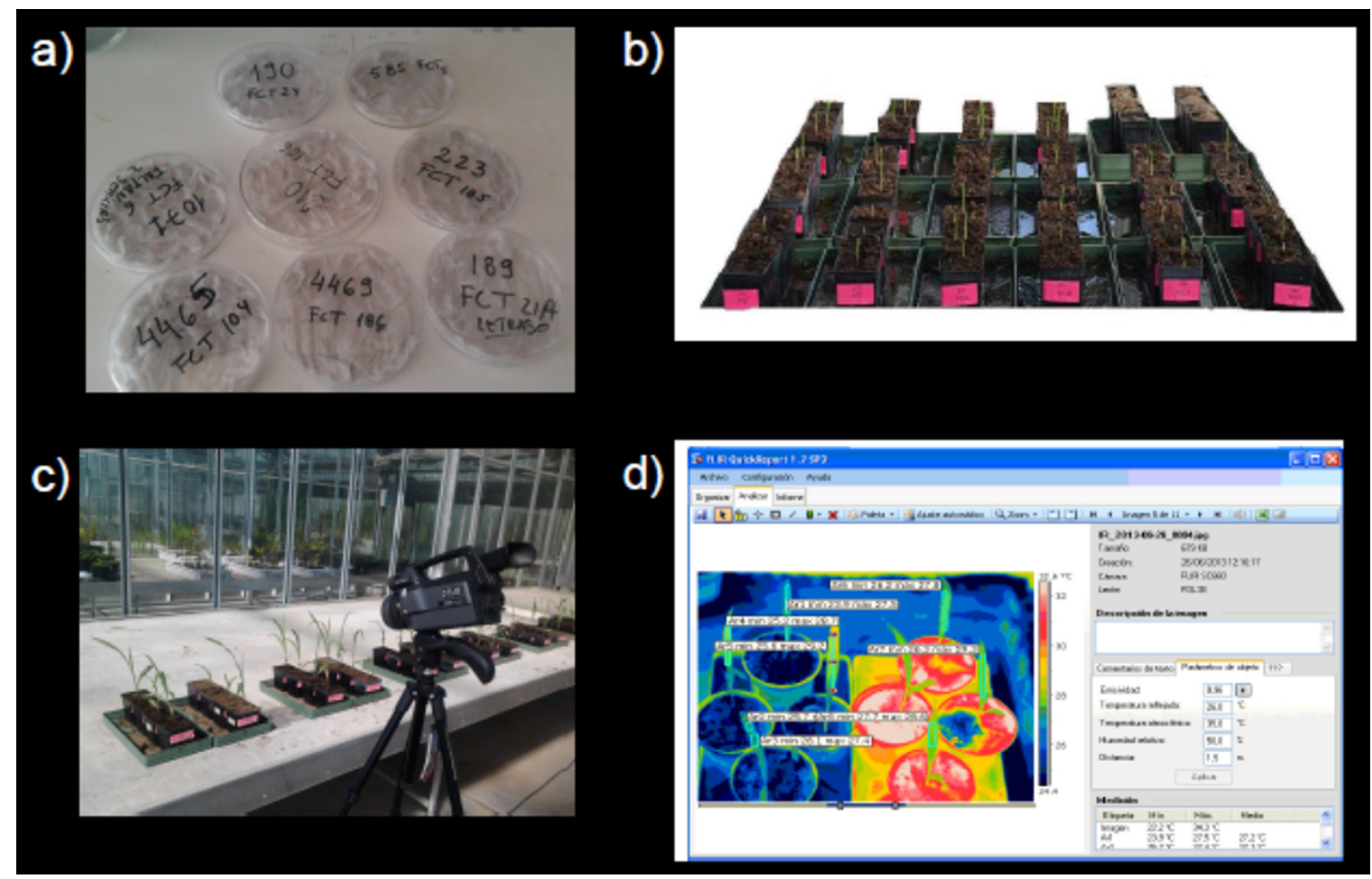

Figure 1. Pre-germination of maize seeds in Petri dishes with filter paper (a), young seedlings with 3-4 true leaves growing in the greenhouse (b); thermal imaging set up, by using a ThermaCAM (Flir SC660) and Flir Systems, USA, 7-13 $\mu$ m, 640x480 pixels) with an emissivity set at 0.96 (c), and false colored thermal image being analysed and processed by using the software FLIR QuickReport (Flir Systems Inc., USA) (d).

During each experiment, plant height was manually measured at three different moments: before stress $\left(B_{s}\right)$, at maximum stress $\left(M_{S}\right)$, and at end of recovery $\left(R_{C}\right)$, taking these measurements in four plants per variety and irrigation treatment.

\section{Data analysis}

Following the recommendations of Liv et al. (2011), to minimize the effect of variation of environmental conditions in the greenhouse, the absolute temperature values were normalized by calculating the temperature difference between leaves of $\mathrm{FI}$ and $\mathrm{NI}$ plants $\left(\Delta \mathrm{T}_{\mathrm{N}-\mathrm{Fl}}\right)$ for each Landrace. According to this methodology, $\Delta \mathrm{T}_{\mathrm{NI}-\mathrm{FI}}$ was considered as the main parameter to assess differences between maize varieties in relation to its response to drought and capability of drought resistance. An exploratory and descriptive analysis of $\Delta T_{\mathrm{N}-\mathrm{Fl}}$ was made, followed by a oneway analysis of variance (ANOVA) applying a post hoc Tukey test $(p<0.05)$ for multiple comparisons to identify the differences in $\Delta \mathrm{T}_{\mathrm{N}-\mathrm{F}}$ between landraces. Additionally, a Student's t-test $(p<0.05)$ was applied to test the differences in the absolute leaf temperature and plant eight 
values between $\mathrm{Fl}$ and $\mathrm{NI}$ for each landrace and sampling day.

DOY 247

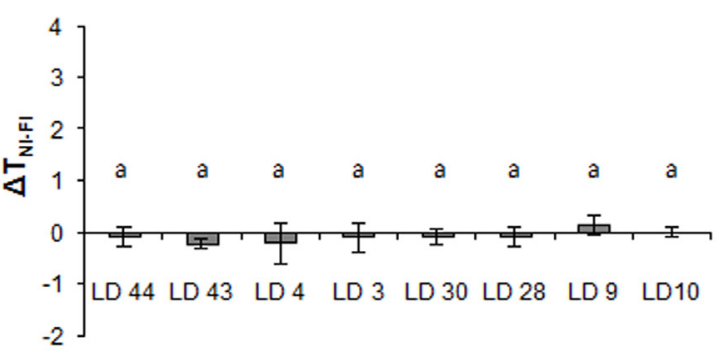

DOY 252

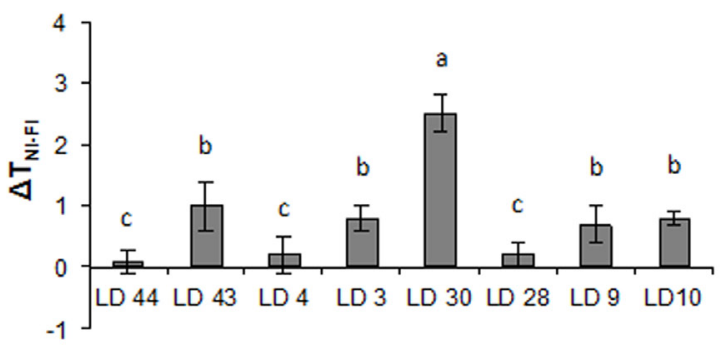

\section{Results and discussion}

Different patterns in $\Delta \mathrm{T}_{\mathrm{NI}-\mathrm{Fl}}$ were observed for the tested LDs (Figure 2).

DOY 249

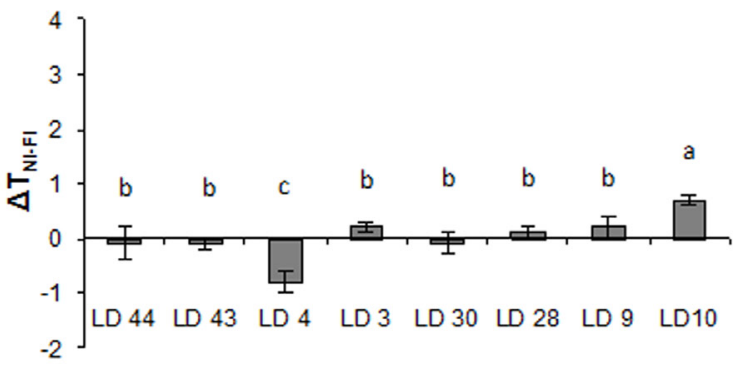

DOY 255

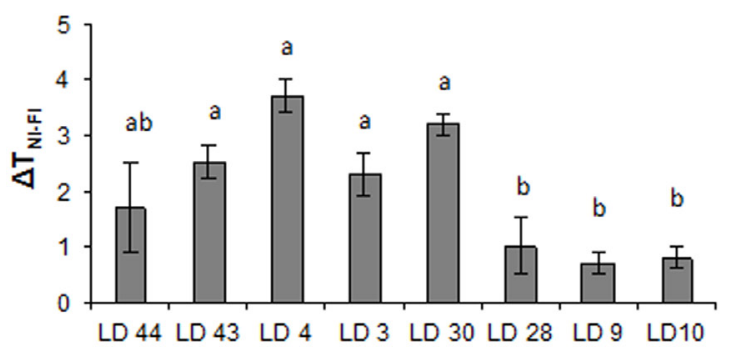

DOY 259 (Recovery)

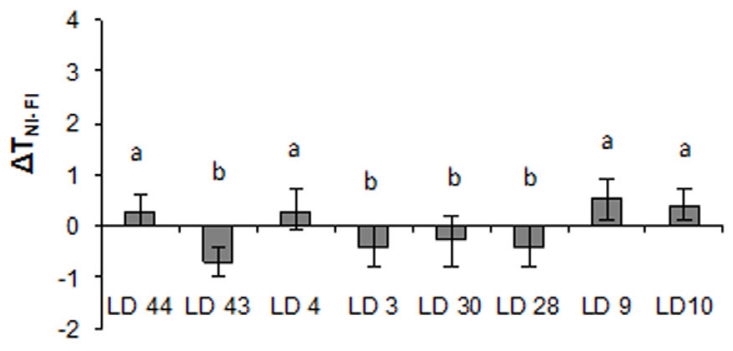

Figure 2. Temporal evolution of leaf temperature difference between maize seedlings continuously irrigated (FI) and non-irrigated followed by re-watering (NI) $\left(\Delta \mathrm{T}_{\mathrm{N}-\mathrm{f}-\mathrm{f}}\right)\left({ }^{\circ} \mathrm{C}\right)$ estimated from thermal images in Experiment I at different DOY (rewatering occurred on DOY 255 after taking images). Values are means and vertical lines are the standard error $(n=4)$. Different letters show significant differences in $\Delta \mathrm{T}_{\mathrm{N}-\mathrm{fl}}$ between the different landraces by Scott-Knott's test $(\mathrm{p}<0.05)$.

During Experiment I, the first significant differences between $\mathrm{FI}$ and $\mathrm{NI}$ plants were found five days after water stress was imposed (Table 2, DOY 252). These significant differences were observed in the LD30, followed by landraces 43, 44, 3 and 4 eight days after imposing water stress. The effects of water stress were significant more expressed in the LD 4 and LD 30 which showed the largest values of $\Delta \mathrm{T}_{\mathrm{NI}-\mathrm{FI}}$ (Up to $3^{\circ} \mathrm{C}$ ) at maximum stress (255 DOY), followed by LDs 43 and 4. Four days after rewatering (DOY 259), we found rather similar temperatures in $\mathrm{Fl}$ and $\mathrm{NI}$ plants (Table 2) with $\Delta T_{N I-F l}$ close to $0^{\circ} \mathrm{C}$ in all LDs (Fig 2). The smaller $\Delta \mathrm{T}$ shortly after rewatering indicates a fast recovery after maximum stress, which is an important characteristic in both physiological and agronomical terms because it indicates the absence of permanent physiological damages caused by drought and the recovery capacity of the plants/genotypes after drought (Carvalho et al., 2011 ; Sapeta et al., 2013).

In Experiment II, the first differences between $\mathrm{Fl}$ and $\mathrm{NI}$ plants were found five days after water with holding (Table 3, 280 DOY), which was in line with the results of the first trial, being the LDs 4 and 44 were the first significant differences were found (Figure 3 ). 
Table 2. Absolute values of temperature in full irrigated and non-irrigated plants during the Experiment I

\begin{tabular}{|c|c|c|c|c|c|c|}
\hline \multirow{2}{*}{ Landraces } & \multirow{2}{*}{ Treatment } & \multicolumn{5}{|c|}{ DOY } \\
\hline & & 247 & 249 & 252 & 255 & 259 \\
\hline \multirow[t]{2}{*}{ LD 44} & $\mathrm{Fl}$ & $29.4 \pm 0.1$ & $29.4 \pm 0.2$ & $30.1 \pm 0.2$ & $34.6 \pm 0.4^{*}$ & $29.3 \pm 0.2$ \\
\hline & $\mathrm{NI}$ & $29.3 \pm 0.2$ & $29.3 \pm 0.4$ & $30.2 \pm 0.3$ & $36.3 \pm 0.2 *$ & $29.6 \pm 0.2$ \\
\hline \multirow[t]{2}{*}{ LD 43} & $\mathrm{Fl}$ & $29.4 \pm 0.3$ & $30.5 \pm 0.3$ & $31.0 \pm 0.4$ & $34.7 \pm 0.5^{*}$ & $31.6 \pm 0.2$ \\
\hline & $\mathrm{NI}$ & $29.2 \pm 01$ & $34.4 \pm 0.2$ & $32.0 \pm 0.4$ & $37.2 \pm 0.3^{*}$ & $30.9 \pm 0.6$ \\
\hline \multirow[t]{2}{*}{ LD 4} & $\mathrm{Fl}$ & $29.6 \pm 0.2$ & $31.9 \pm 0.2$ & $32.2 \pm 0.2$ & $35.2 \pm 0.4^{*}$ & $31.5 \pm 0.3$ \\
\hline & $\mathrm{NI}$ & $29.4 \pm 0.1$ & $31.1 \pm 0.2$ & $32.4 \pm 0.1$ & $38.9 \pm 0.6^{*}$ & $31.8 \pm 0.2$ \\
\hline \multirow[t]{2}{*}{ LD 3} & $\mathrm{Fl}$ & $29.4 \pm 0.2$ & $29.4 \pm 0.1$ & $30.1 \pm 0.4$ & $34.2 \pm 0.4^{*}$ & $30.5 \pm 0.2$ \\
\hline & $\mathrm{NI}$ & $29.3 \pm 0.2$ & $29.6 \pm 0.1$ & $30.9 \pm 0.3$ & $36.5 \pm 0.3^{*}$ & $30.1 \pm 0.3$ \\
\hline \multirow[t]{2}{*}{ LD 30} & $\mathrm{Fl}$ & $30.8 \pm 0.4$ & $30.8 \pm 0.2$ & $32.1 \pm 0.2^{*}$ & $35.4 \pm 0.4^{*}$ & $31.1 \pm 0.3$ \\
\hline & $\mathrm{NI}$ & $30.7 \pm 0.2$ & $30.7 \pm 0.1$ & $34.6 \pm 0.4^{*}$ & $38.6 \pm 0.5^{*}$ & $30.8 \pm 0.2$ \\
\hline \multirow[t]{2}{*}{ LD 28} & $\mathrm{Fl}$ & $29.5 \pm 0.5$ & $29.7 \pm 0.2$ & $30.5 \pm 0.4$ & $34.6 \pm 0.5$ & $30.6 \pm 0.4$ \\
\hline & $\mathrm{NI}$ & $29.4 \pm 0.2$ & $29.8 \pm 0.1$ & $30.7 \pm 0.3$ & $35.6 \pm 0.3$ & $30.2 \pm 0.3$ \\
\hline \multirow[t]{2}{*}{ LD 9} & $\mathrm{Fl}$ & $29.5 \pm 0.2$ & $29.9 \pm 0.1$ & $31.0 \pm 0.3$ & $33.6 \pm 0.5$ & $30.0 \pm 0.6$ \\
\hline & $\mathrm{NI}$ & $29.7 \pm 0.1$ & $30.1 \pm 0.2$ & $31.7 \pm 0.4$ & $34.3 \pm 0.2$ & $30.5 \pm 0.2$ \\
\hline \multirow[t]{2}{*}{ LD 10} & $\mathrm{Fl}$ & $29.3 \pm 0.2$ & $30.7 \pm 0.1$ & $31.3 \pm 0.2$ & $35.1 \pm 0.3$ & $31.3 \pm 0.4$ \\
\hline & $\mathrm{NI}$ & $29.3 \pm 0.3$ & $31.4 \pm 0.2$ & $32.2 \pm 0.1$ & $35.9 \pm 04$ & $31.7 \pm 0.3$ \\
\hline
\end{tabular}

After 7 days without irrigation only LD10,

LD9 and LD28 showed no significant differences in absolute temperature values between $\mathrm{FI}$ and $\mathrm{NI}$ plants. In opposite direction, LD4 and LD30 showed larger $\Delta \mathrm{T}_{\mathrm{NI}-\mathrm{Fl}}$ (up to $3.5^{\circ} \mathrm{C}$, Figure 3) suggesting differences between genotypes in terms of the response to water stress. It is noticeable that, at maximum stress (282 DOY), LD4, LD30, LD43, LD3, and LD44 had the largest $\Delta \mathrm{T}_{\mathrm{NI}-\mathrm{Fl}}$, with a pattern very similar to this found in the Experiment I, these LDs being typically grown at the lowest latitudes, and potentially subjected to less water stress in their native habitat. After rewatering, all landraces, except LD44, presented similar $\Delta \mathrm{T}_{\mathrm{NI}-\mathrm{Fl}}$ (around $\pm 0.5^{\circ} \mathrm{C}$ ) (Figure 3 ).

Taking into account the whole data, LD28 was the most tolerant to water stress, because leaf temperature values were rather constant (with minor $\Delta \mathrm{T}_{\mathrm{N}-\mathrm{F}}$ ) even, under maximum stress. In contrast LD4, LD30, LD3 and LD44 presented large $\Delta \mathrm{T}_{\mathrm{N}-\mathrm{Fl}}$ suggesting higher sensitiveness to water stress, and most probably a more strict stomatal control under dry conditions. However, this fact is not properly a disadvantage to water stress management by the plant. In this sense, if plants are subjected to a mild-water stress during a short time period, a strict stomatal control could be not positive. However, if a mild-water stress were kept along the time, only those plants that were been able to respond with a strict stomatal conductance from the beginning would have the possibility of resisting to a severe drought.
In general, the LDs behaved similarly during the two experiments. LD10, LD9 and LD28 showed smaller changes in leaf temperature. In the case of LD10 and LD9, they come from higher altitudes, suggesting a relation between the variety response to drought and the climate where they are traditionally grown.

Thermal imaging has been successfully used as an effective tool for large scale screens of mutants of model species such as Arabidopsis, but the use of similar approach in maize breeding seems also feasible (Costa et al., 2013). Maize is an isohydric species, with a stricter stomatal control, which is well suited for thermographical monitoring (Liu et al., 2011; Mazuka et al., 2012). Liv et al. (2011) found that lower leaf temperatures under dry conditions were positively correlated to biomass accumulation, suggesting the possibility of using this technique for maize phenotyping in relation to water stress. Besides, punctual measurements of leaf gas exchange or leaf temperature (infrared thermometers) are slow and time consuming and not practical for largescale measurements. Thermal imaging has the important advantage that it can be used with plants of different sizes, under either controlled or field conditions (Walter et al., 2012; Costa et al., 2013). The fact that plants were grown under greenhouse conditions allowed more constant environmental conditions and minimize the effects of wind, which in field conditions could promote artificial leaf cooling (Liv et al., 2011). 
This is in line with previous study reporting that more clear and significant differences between

DOY 275

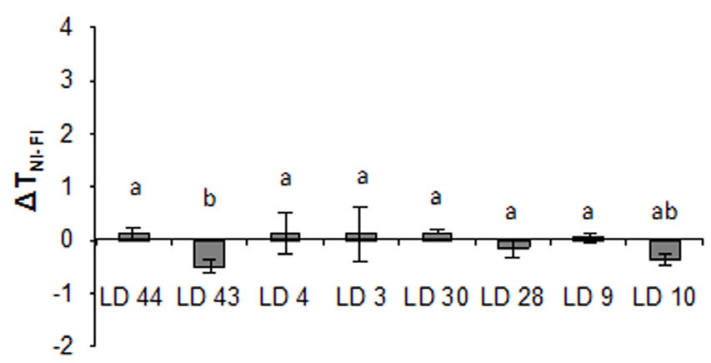

DOY 280

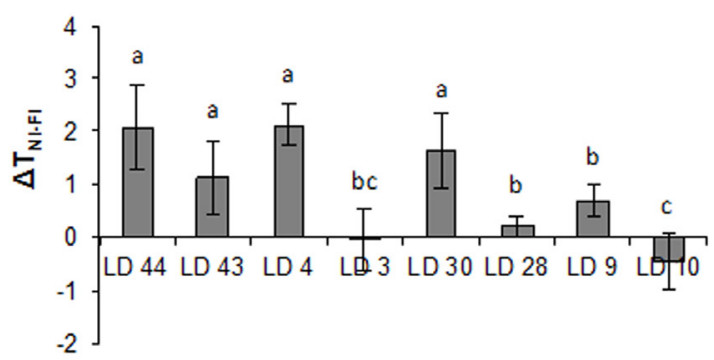

irrigation treatments were achieved by the time of larger stress (Costa et al., 2012, 2013).
DOY 278

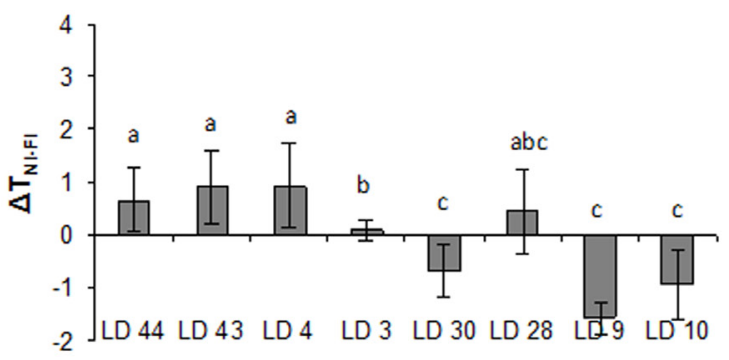

DOY 282

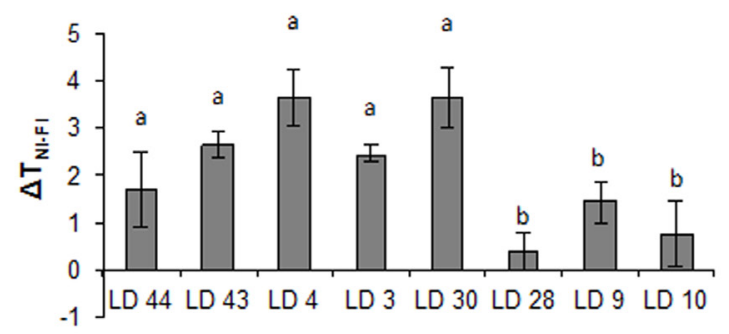

DOY 288 (Recovery)

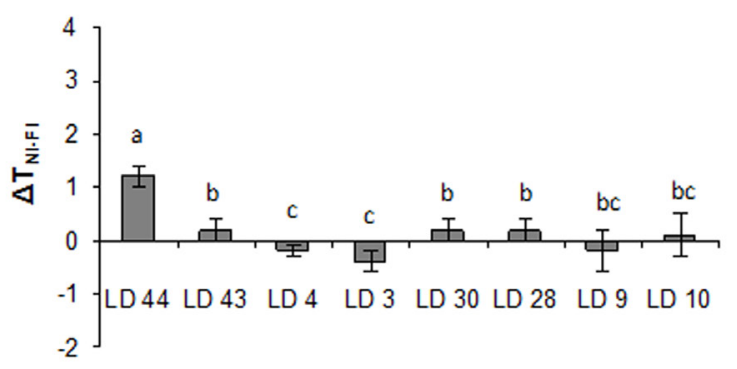

Figure 3. Temporal evolution of leaf temperature difference between maize seedlings continuously irrigated (FI) and non-irrigated followed by re-watering $(\mathrm{NI})\left(\Delta \mathrm{T}_{\mathrm{NEF}}\right)\left({ }^{\circ} \mathrm{C}\right)$ estimated from thermal images in Experiment II at different DOY (rewatering occurred on DOY 282 after taking images). Values are means and vertical lines are the standard error $(n=4)$. Different letters show significant differences in $\Delta \mathrm{T}_{\mathrm{N} \cdot \mathrm{Fl}}$ between the different landraces by Scott-Knott's test $(\mathrm{p}<0.05)$.

Another approach for phenotyping maize is described by Carvalho et al. (2011), who characterized six Portuguese maize inbred lines, based on the evolution of relative water content (RWC), leaf gas-exchange and Chl fluorescence. They found that all genotypes showed a decrease in RWC, stomatal conductance and net photosynthesis under drought and that after recovering, not all genotypes recovered the initial values under non-stressed conditions. Similarly, in the present study we found that LD44 was not able to show a full recovery after rehydration, which suggest permanent damages after drought in terms of vegetative development.
It is possible that a higher number of replicates would result in more clear results and eventual differences between genotypes. Moreover, thermal imaging measurements need also to be validated by leaf gas exchange measurements, to conclude on the effect of stomatal conductance to water vapour on the temperature differences found between genotypes. Leaf morphology (stomatal density, stomata morphology) or other variables such as root biomass should also be analyzed. Future studies should take into account eventual differences at development stages in order to better understand maize's response to water 
Table 3. Absolute values of temperature in full irrigated and non- irrigated plants during the Experiment II

\begin{tabular}{|c|c|c|c|c|c|c|}
\hline \multirow{2}{*}{ Landraces } & \multirow{2}{*}{ Treatment } & \multicolumn{5}{|c|}{ DOY } \\
\hline & & 275 & 278 & 280 & 282 & 288 \\
\hline \multirow[t]{2}{*}{ LD 44} & $\mathrm{FI}$ & $28.1 \pm 0.3$ & $32.1 \pm 0.3$ & $33.8 \pm 0.2^{*}$ & $33.5 \pm 0.2^{*}$ & $28.5 \pm 0.3$ \\
\hline & $\mathrm{NI}$ & $28.2 \pm 0.2$ & $32.7 \pm 0.2$ & $35.9 \pm 0.2^{*}$ & $35.2 \pm 0.3^{*}$ & $29.7 \pm 0.2$ \\
\hline \multirow[t]{2}{*}{ LD 43} & $\mathrm{FI}$ & $28.8 \pm 0.5$ & $33.0 \pm 0.1$ & $35.2 \pm 0.3$ & $33.9 \pm 0.1^{*}$ & $26.2 \pm 0.2$ \\
\hline & $\mathrm{NI}$ & $28.3 \pm 0.2$ & $33.9 \pm 0.6$ & $36.3 \pm 0.2$ & $36.5 \pm 0.5^{*}$ & $26.4 \pm 0.6$ \\
\hline \multirow[t]{2}{*}{ LD 4} & $\mathrm{FI}$ & $28.6 \pm 0.4$ & $33.3 \pm 0.4$ & $35.2 \pm 0.3^{*}$ & $32.7 \pm 0.4^{*}$ & $25.6 \pm 0.5$ \\
\hline & $\mathrm{NI}$ & $28.7 \pm 0.6$ & $34.2 \pm 0.3$ & $37.3 \pm 0.1^{*}$ & $36.3 \pm 0.3^{*}$ & $25.4 \pm 0.4$ \\
\hline \multirow[t]{2}{*}{ LD 3} & $\mathrm{FI}$ & $28.3 \pm 0.3$ & $33.3 \pm 0.2$ & $35.2 \pm 0.2$ & $34.4 \pm 0.2^{*}$ & $28.5 \pm 0.3$ \\
\hline & $\mathrm{NI}$ & $28.4 \pm 0.5$ & $33.4 \pm 0.2$ & $35.2 \pm 0.5$ & $36.8 \pm 0.2^{*}$ & $28.1 \pm 0.2$ \\
\hline \multirow[t]{2}{*}{ LD 30} & $\mathrm{FI}$ & $28.9 \pm 0.4$ & $34.2 \pm 0.3$ & $36.3 \pm 0.4$ & $33.8 \pm 0.3^{*}$ & $25.3 \pm 0.2$ \\
\hline & $\mathrm{NI}$ & $29.0 \pm 0.3$ & $33.5 \pm 0.1$ & $37.9 \pm 0.3$ & $37.4 \pm 0.5^{*}$ & $25.5 \pm 0.3$ \\
\hline \multirow[t]{2}{*}{ LD 28} & $\mathrm{FI}$ & $28.5 \pm 0.2$ & $32.1 \pm 0.5$ & $33.5 \pm 0.6$ & $33.4 \pm 0.4$ & $26.9 \pm 0.2$ \\
\hline & $\mathrm{NI}$ & $28.3 \pm 0.1$ & $32.5 \pm 0.3$ & $33.7 \pm 0.3$ & $33.8 \pm 0.2$ & $27.1 \pm 0.3$ \\
\hline \multirow[t]{2}{*}{ LD 9} & $\mathrm{FI}$ & $28.1 \pm 0.3$ & $33.0 \pm 0.5$ & $34.8 \pm 0.3$ & $33.8 \pm 0.1$ & $27.3 \pm 0.4$ \\
\hline & $\mathrm{NI}$ & $28.2 \pm 0.2$ & $31.4 \pm 0.6$ & $35.5 \pm 0.2$ & $35.3 \pm 0.2$ & $27.1 \pm 0.5$ \\
\hline \multirow[t]{2}{*}{ LD 10} & $\mathrm{FI}$ & $28.8 \pm 0.1$ & $33.2 \pm 0.1$ & $36.4 \pm 0.2$ & $34.5 \pm 0.4$ & $25.8 \pm 0.3$ \\
\hline & $\mathrm{NI}$ & $28.4 \pm 0.2$ & $32.3 \pm 0.3$ & $35.9 \pm 0.3$ & $35.3 \pm 0.3$ & $25.9 \pm 0.4$ \\
\hline
\end{tabular}

stress. Thus, considering the complexity of those mechanisms involved in drought tolerance, thermal imaging can work only as a supportive tool of a preliminary screen which can help to identify a group of the most promising genotypes in terms of their resistance to drought stress.

Regarding plant growth, during the Experiment I, height of the landraces LD10, LD43, LD28, LD3 and LD44 was not negatively affected by short-term drought and tLD30 showed a decrease at Ms but recovered after re-watering (Table 4). In Experiment II, only the landraces LD28 and LD10 showed similar height in NI and FI conditions, whereas the landraces LD4, LD30, LD43, LD9 and LD44 showed a decrease by about $44,19,29,45$, and $15 \%$ respectively by the end of the experiment. Only LD3 showed partial re-growth after rehydration.

Overall, these results agree with those relative to leaf temperature. Therefore, certain LDs tested in our study, in particular LD28 and LD10, are characterized by lower values of $\Delta \mathrm{T}_{\mathrm{N}-\mathrm{FI}}$ and had similar growth under $\mathrm{NI}$ and $\mathrm{FI}$ conditions. This is in line with the findings of Liv et al. (2011) in maize, who argued that growth under drought could be closely related to leaf temperature, and that temperature could be a robust indicator of water stress on the plant biomass accumulation. of maize seedlings and $\Delta \mathrm{T}_{\mathrm{N}-\mathrm{Fl}}$ can work as an indicator parameter of sensitivity to water stress and of water status of the plants.

We found a relation between the cultivation characteristics (high altitude vs. low altitude) and landrace response to water stress suggesting that thermal imaging can be a supportive tool in the preliminary characterization of maize landraces, taking as indication the index $\Delta \mathrm{T}_{\mathrm{N}-\mathrm{F}}$.

However, more studies should be developed In order to corroborate these results and even, study more traditional landraces in terms of water stress or other abiotic stress situations.

\section{Acknowledgements}

This work is the result of collaboration between the Molecular Ecophysiology Laboratory, the Plant Cell Biotechnology Laboratory, both from Instituto de Tecnologia Química e Biológica (ITQB - Universidade Nova de Lisboa) and the Group of Environment and Natural Resources Production of IFAPA 'Las Torres - Tomejil'. The author I. García-Tejero received a contract co-financed by the European Social Fund Operational Programme (FSE) 2007 - 2013. "Andalusia is moving with Europe".

\section{Conclusions}

Thermal imaging is a suitable and fast approach to monitor the physiological condition 
Table 4. Plant height measured for maize seedlings of each landrace at three different stages

\begin{tabular}{|c|c|c|c|c|c|}
\hline \multirow{2}{*}{ Landrace } & \multirow{2}{*}{ Stage } & \multicolumn{2}{|c|}{ Experiment I } & \multicolumn{2}{|c|}{ Experiment II } \\
\hline & & $\mathrm{FI}$ & $\mathrm{NI}$ & $\mathrm{Fl}$ & $\mathrm{NI}$ \\
\hline \multirow{3}{*}{ LD 44} & $\mathrm{~B}_{\mathrm{s}}$ & $19.6 \pm 5.2$ & $19.4 \pm 5.5$ & $20.7 \pm 5.1$ & $20.1 \pm 6.7$ \\
\hline & $M_{s}$ & $31.8 \pm 5.9$ & $29.4 \pm 1.7$ & $58.6 \pm 9.4$ & $49.8 \pm 2.8^{*}$ \\
\hline & $R_{C}$ & $31.9 \pm 7.2$ & $31.9 \pm 6.5$ & $63.2 \pm 3.1$ & $54.7 \pm 6.6^{*}$ \\
\hline \multirow{3}{*}{ LD 43} & $\mathrm{~B}_{\mathrm{s}}$ & $21.1 \pm 1.5$ & $21.8 \pm 4.5$ & $17.7 \pm 2.5$ & $14.3 \pm 6.0$ \\
\hline & $M_{s}$ & $30.8 \pm 3.3$ & $32.8 \pm 5.8$ & $53.8 \pm 3.3$ & $37.7 \pm 6.3^{*}$ \\
\hline & $R_{C}$ & $32.5 \pm 4.8$ & $34.7 \pm 5.5$ & $57.1 \pm 2.2$ & $44.2 \pm 3.6^{*}$ \\
\hline \multirow{3}{*}{ LD 4} & $\mathrm{~B}_{\mathrm{s}}$ & $20.0 \pm 5.4$ & $19.6 \pm 7.3$ & $17.5 \pm 5.8$ & $18.6 \pm 2.3$ \\
\hline & $M_{s}$ & $33.5 \pm 8.8$ & $21.9 \pm 9.2^{*}$ & $51.6 \pm 5.7$ & $38.8 \pm 2.3^{*}$ \\
\hline & $R_{C}$ & $35.5 \pm 10.4$ & $24.6 \pm 9.9^{*}$ & $57.8 \pm 3.2$ & $40.2 \pm 3.1^{*}$ \\
\hline \multirow{3}{*}{ LD 3} & $B_{S}$ & $20.8 \pm 2.0$ & $20.7 \pm 4.4$ & $17.6 \pm 6.5$ & $17.8 \pm 3.2$ \\
\hline & $M_{s}$ & $30.9 \pm 2.5$ & $30.5 \pm 5.0$ & $56.4 \pm 3.1$ & $47.7 \pm 2.7^{*}$ \\
\hline & $R_{C}$ & $35.2 \pm 7.2$ & $34.1 \pm 5.9$ & $59.3 \pm 5.2$ & $55.4 \pm 5.2$ \\
\hline \multirow{3}{*}{ LD 30} & $\mathrm{~B}_{\mathrm{s}}$ & $20.6 \pm 12.8$ & $20.6 \pm 4.3$ & $19.8 \pm 1.2$ & $20.8 \pm 3.3$ \\
\hline & $M_{s}$ & $35.3 \pm 6.7$ & $28.6 \pm 5.6^{*}$ & $60.9 \pm 3.7$ & $48.0 \pm 9.6^{*}$ \\
\hline & $R_{C}$ & $37.4 \pm 8.2$ & $35.2 \pm 4.7$ & $65.7 \pm 6.3$ & $55.2 \pm 4.6^{*}$ \\
\hline \multirow{3}{*}{ LD 28} & $\mathrm{~B}_{\mathrm{S}}$ & $21.7 \pm 1.8$ & $22.1 \pm 3.43$ & $18.3 \pm 3.5$ & $20.8 \pm 1.3$ \\
\hline & $M_{s}$ & $31.1 \pm 1.7$ & $30.1 \pm 8.7$ & $41.4 \pm 4.9$ & $40.4 \pm 3.0$ \\
\hline & $R_{C}$ & $33.2 \pm 2.2$ & $32.5 \pm 5.6$ & $48.7 \pm 6.6$ & $49.3 \pm 7.3$ \\
\hline \multirow{3}{*}{ LD 9} & $\mathrm{~B}_{\mathrm{S}}$ & $21.4 \pm 2.7$ & $21.7 \pm 1.8$ & $6.8 \pm 1.1$ & $9.3 \pm 2.0$ \\
\hline & $M_{s}$ & $32.0 \pm 6.4$ & $24.9 \pm 5.4^{*}$ & $32.5 \pm 7.2$ & $22.2 \pm 5.2^{*}$ \\
\hline & $R_{C}$ & $34.1 \pm 7.9$ & $28.3 \pm 3.2^{*}$ & $39.8 \pm 2.1$ & $27.4 \pm 5.3^{*}$ \\
\hline \multirow{3}{*}{ LD 10} & $\mathrm{~B}_{\mathrm{s}}$ & $15.2 \pm 2.8$ & $14.8 \pm 5.6$ & $16.2 \pm 1.1$ & $15.2 \pm 5.0$ \\
\hline & $M_{s}$ & $29.3 \pm 2.2$ & $25.0 \pm 4.1$ & $52.7 \pm 9.7$ & $50.4 \pm 1.8$ \\
\hline & $R_{C}$ & $25.7 \pm 6.0$ & $30.7 \pm 3.2$ & $59.4 \pm 3.2$ & $60.2 \pm 7.1$ \\
\hline
\end{tabular}

\section{References}

Costa, J.M., Ortuño, M.F., Lopes, C.M., Chaves, M.M. 2012. Grapevine varieties exhibiting differences in stomatal response to water deficit. Functional Plant Biology 39: 179-189.

Costa, J.M., Grant, O.M., Chaves, M.M. 2013. Thermography to explore plant-environment interactions. Journal of Experimental Botany 64: 3937-3949.

Carvalho, R.C., Cunha, A., da Silva, J.M. 2011. Photosynthesis by six Portuguese maize cultivars during drought stress and recovery. Acta Physiologiae Plantarum 33: 359-374.

Farré, I., Faci, J.M. 2006. Comparative response of maize (Zea mays L.) and sorghum (Sorghum bicolor L. Moench) to deficit irrigation in a Mediterranean environment. Agricultural Water Management 83: 135-143.

García-Tejero, I.F., Durán-Zuazo, V.H., Muriel, J.L., Jiménez-Bocanegra, J.A. 201 la. Linking canopy temperature and trunk diameter fluctuations with other physiological water status tools for water stress management in citrus orchards. Functional Plant Biology 38: 106-117.

García-Tejero, I.F., Durán-Zuazo, V.H., MurielFernández, J.L., Rodríguez-Pleguezuelo, C.R. $2011 \mathrm{~b}$. Water and sustainable agriculture. Springer, Munich, Germany. 94 p.

García-Tejero, I.F., Muriel, J.L., Durán-Zuazo, V.H., Arriaga, J. 2013. Uso eficiente del agua en la agricultura. Instituto de Investigación y Formación Agraria y Pesquera. Consejería de Agricultura, Pesca y Desarrollo Rural, Madrid, Spain.109 p.

Hoeft, R.G., Nafziger, E.D., Johnson, R.R., Aldrich, S.R. 2000. Modern Corn and SoybeanProduction. First Edition. MCSP Publications, Yorkshire, USA.353p.

James, R.A., Siraut, X.R.R. 2012. Infrared thermography in plant phenotyping for salinity tolerance. In: Shabala, S.; Cuin, T.A. Plant salt 
tolerance: methods and protocols. Methods in molecular biology Series. p: 173 - 189.

Jones, H.G. 1992. Plants and microclimate. $2^{\text {nd }}$ ed. Cambrigde University Press, Cambrigde, UK.423 p.

Jones, H.G. 1999. Use of infrared thermometry for estimation of stomatal conductance as a possible aid to irrigation schedule. Agricultural Water Management 95: 139-149.

Jones, H.G., Stoll, M., Santos, T., de Souza, C., Chaves, M.M., Grant, O.M. 2002. Use of infrared thermography for monitoring stomatal closure in the field: application to grapevine. Journal of Experimental Botany 53: 1-12.

Jones, H.G., Vaughan, R.A. 2010. Remote sensing of vegetation: principles, techniques and applications. Oxford University Press, Oxford, UK. $384 \mathrm{p}$.

Kummerlen, B., Dauwe, S., Schmundt, D., Schurr, U. 1999. Thermography to measure water relations of plant leaves. In: Jähne, B., Havecker, H., Geiler, P. (Eds.), Handbook of Computer Vision and Applications: Systems and Applications. Academic Press, Heidelberg, Germany. p. 763781.

Liu, Y., Subhash, C., Yan, J., Song, C., Zhao, J., Li, J. 2011. Maize leaf temperature responses to drought: Thermal imaging and quantitative trait loci (QTL) mapping. Environmental and Experimental Botany 71: 158-165.

Long, S.P., Bernacchi, C.J. 2003. Gas exchange measurements, what can they tell us about the underlying limitations to photosynthesis? Procedures and sources of error. Journal of Experimental Botany 54: 2393-2401.

Masuka, B., Araus, J.L., Das, B., Sonder, K., Cairns, J.E. 2012. Phenotyping for abiotic stress tolerance in maize. Journal of Integrative Plant Biology 54: 238-249.

Mendes-Moreira, P., Pego, S., Vaz Patto, M.C., Hallaver, A. 2008. Comparison of selection methods on 'Pigarro', a Portuguese improved maize population with fasciation expression. Euphytica 163: 481-499.

Mendes-Moreira, P., Vaz Patto, M.C., Mota, M.M., Mendes-Moreira, J.J., Santos, J.P.N., Santos, J.P.P., Andrade, E., Hallaver, A.R., Pego, S.E. 2009. Fandango: long term adaptation of exotic germplasm to a Portuguese on-farmconservation andbreeding project. Maydica 54: 269-285.

Pêgo, S., Antunes, M.P. 1997. Resistance or tolerance? Philosophy may be the answer. In: Pego S, Martins R. (eds.) Proceedings of the XIX
Conference of the International Working Group on Ostrinia nubilabis and other maize pests. Proceedings...IWGO, Guimarães, Portugal.p. 303-341.

Sapeta, H., Costa, J.M., Lourenço, T., Maroco, J., van der Linde, P., Oliveira, M.M. 2013. Drought stress response in Jatropha curcas: growth and physiology. J EnvExp Bot 85: 7684.

Vasconcellos e Souza, L. 2012. A producção do milho em Portugal. Agrotec 2: 53-54.

Vaz Patto, M.C., Satovic, Z., Pego, S., Fevereiro, P. 2004. Assessing the genetic diversity of Portuguese maizegermplasm using microsatellite markers. Euphytica 137: 63-72.

Vaz Patto, M.C., Moreira, P.M., Carvalho, V., Pego, S. 2007. Collecting maize (Zea mays L. convar. mays) with potential technological ability for bread making in Portugal. Genetic Resources and Crop Evolution 54: 1555-1563.

Vaz Patto, M.C., Moreira, P., Almeida, N., Satovic, Z., Pego, S. 2008. Genetic diversity evolution through participatory maize breeding in Portugal. Euphytica 161: 283-291.

Vaz Patto, M.C., Alves, M.L., Almeida, N.F., Santos, C., Mendes-Moreira, P., Satovic, Z., Brites, C. 2009. Is the bread making technological ability of Portuguese traditional maize landraces associated with their genetic diversity? Maydica 54: 297-311.

Vaz Patto, M.C., Mendes-Moreira, P.M., Alves, M.L., Mecha, E., Brites, C., Bronze, R., Pego, S. 2013. Participatory plant quality breeding: an ancient art revisited by knowledge sharing. The Portuguese experience. In: Andersen, S.B. Plant breeding from laboratories to fields. InTech, Rijeka, Croatia. p. 255-288.

Walter, A., Studer, B., Kölliker, R. 2012.Advanced phenotyping offers opportunities for improved breeding of forage and turf species. Annals of Botany 110: 1271-1279. 